\title{
Prognostic Value of Dysnatremia in COVID-19 Disease
}

\author{
COVID-19 Hastalığında Sodyumun Anormal Değerlerinin \\ Prognoza Etkisi
}

Özgün Araştrrma Research Article
Received/Gelis: 23.08.2021 Accepted/Kabul: 24.08.2021 Published Online:

Şeyda Kayhan Ömeroğlu izmir Suat Zeren Araştırma Hastanesi Anesteziyoloji Bölümü, izmir, Türkiye seyda.kayhan@hotmail.com ORCID: 0000-0003-1830-8831

M.B. Öztop 0000-0003-2713-6381 İmir Bakırçay Üniversitesi Cerrahi Anabilim Dalı, İzmir, Türkiye

Cite as: Kayhan Ömeroğlu ș, Öztop MB. Prognostic value of dysnatremia in Covid-19 disease. Tepecik Eğit. ve Araşt. Hast. Dergisi. 2021;31(3):

\author{
Şeyda Kayhan Ömeroğlu $\oplus$, Mehmet Burak Öztop $\odot$
}

\begin{abstract}
Objective: The infection of Corona 2019 (COVID-19) had first diagnosed in December 2019 and evolved into a worldwide pandemic in March 2020. In Turkey first diagnose was announced in March 2020. Low costed and easily accessible laboratory parameters needed for predicting the prognosis of this disease as its outcome pattern vary greatly from patient to patient. There is promising data on predicting the outcomes with disnatremic results. Methods: In this study we retrospectively investigated all adults with the diagnosis of COVID-19 who attended to Turkan Ozilhan Hospital over a 3 months period. We evaluated the relation of dysnatremia (hyponatremia as $<135$ $\mathrm{mmol} / \mathrm{L}$ or hypernatremia as $>145 \mathrm{mmol} / \mathrm{L}$ ) for need of intensive care unit (ICU) treatment, need of intubation for mechanic ventilatory support and inpatient mortality.

Results: one thousand seventy tree patients with COVID-19 [53..9\% males (793 patients) and 46.1\% females (680 patients), were investigated for this study. Their median age was 53.9 years ranging betweent 19-94. The dysnatremic groups had significantly higher rates of need for ICU and intubation The need for ICU was 89 (21.5\%) patients in normonatremic group but 38 (76\%) patients in hypernatremic and 71 (64\%) in hyponatremic patients ( $p<0.01$ for each of them). The mortality rate was $5 \%$ in normonatremic patients but $50 \%$ in hypernatremic and $28 \%$ in hyponatremic patients ( $p<0.01$ for each of them).

Conclusion: In this study we aimed to draw attention to the importance of abnormal sodium levels as a predictive marker in COVID-19. In small town hospitals the physicians should be aware of the risks of disnatremic patients with COVID-19 and take precautions while treating them.
\end{abstract}

Keywords: Corona, SARS-CoV-2, disnatremia, prognostic criteria

Öz

Amaç: Corona virüs hastalığı 2019 (COVID-19), Aralık 2019'da bașladı ve Mart 2020'de Dünya çapında bir pandemiye dönüştü. Türkiye'de ilk tanı Mart 2020'de açıklandı. Bu hastalığın hangi hastayı nasıl etkilediği bilinmediğinden, prognozu öngörmede laboratuvar testlere çok ihtiyaç duyulmaktadır. Anormal sodyum konsantrasyonunun prognostik etkisi hakkında umut verici veriler vardır.

Yöntem: Bu çalışmada Türkan Özilhan Hastanesi'ne 3 aylık bir süre içinde başvuran COVID-19 tanılı tüm erişkinleri geriye dönük olarak inceledik. Disnatremi (sırasıyla serum sodyum $<135$ ve $>145 \mathrm{mmol} / \mathrm{L}$, hiponatremi ve hipernatremi) ile yoğun bakım ünitesi (YBÜ) tedavisi ihtiyacı, ileri solunum desteği için entübasyon ihtiyacı ve yatan hasta mortalitesi arasındaki ilişkiyi değerlendirdi.

Bulgular: Bu çalışma için toplam 1473 COVID-19 hastası [793 erkek $(\% 53,9)$ ve 680 kadın $(\% 46,1)$, ortanca yaş 56,3 yaşında (aralık, 19-94)] araştırıldı. Disnatremik gruplarda yoğun bakım ve entübasyon ihtiyacı anlamlı olarak daha yüksekti: normonatremik grupta 89 (\%21,5) hastada yoğun bakım ünitesi ihtiyacı olmuşken, hipernatremik hastalarda 38 (\%76) ve hiponatremik hastalarda 71 (\%64) hastada YBÜ tedavisi gerekti ( her ikisi için de $p<0,01)$. Normonatremik hastalarda ölüm oranı $\% 5$ iken, hipernatremik hastalarda \%50 ve hiponatremik hastalarda \%28 idi (her ikisi için de $p<0,01$ ).

Sonuç: Sonuçlarımız, COVID-19'da prediktif belirteç olarak disnatreminin önemini vurgulamaktadır. Özellikle birinci ve ikinci basamak hastanelerinde görev yapan hekimler, COVID-19'lu disnatremik hastaların risklerinin farkında olmalı ve tedavi ederken önlem almalıdır.

Anahtar kelimeler: Korona, SARS-CoV-2, disnatremi, prognostik kriterler

(c) Telif hakkı T.C. Sağlık Bakanlığı İmir Tepecik Eğit. ve Araşt. Hastanesi. Logos Tıp Yayıncılık tarafindan yayınlanmaktadır. Bu dergide yayınlanan bütün makaleler Creative Commons Attf-GayriTicari 4.0 Uluslararası Lisansı ile lisanslanmıștır.

(c) Copyright Association of Publication of the T.C. Ministry of Health Izmir Tepecik Education and Research Hospital.

This journal published by Logos Medical Publishing.

Licenced by Creative Commons Attribution-NonCommercial 4.0 International (CC BY) 


\section{INTRODUCTION}

COVID-19 has started in December 2019 and evolved into a worldwide pandemic in March 2020. In Turkey first diagnose was announced in March $2020^{(1)}$. Now it has been over one year and we learned many new and useful knowledge about COVID-19 and its risk factors for a poor outcome. Older age, male gender, special ethnic groups (Black or Asian), and some comorbidities (type 2 diabetes, obesity, hypertension or cardiovascular diseases) are accepted as predictors for the high mortality risk in COVID-19 (2). The pathologic results of some laboratory findings, such as leukocyte count, renal function tests, liver function tests, cardiac troponin T and D-dimer, as well as low neutropenia and lymphocytopenia with hypoalbuminemia are associated with high mortality during the treatment of the patients in hospital ${ }^{(3)}$. These findings help us to predict those risky patients whom need much more attention.

The well described coagulation pathway activation (4) and the induction of an aggravated inflammatory response ${ }^{(5)}$ are the main reasons of the multiorgan dysfunctions. There are many other disorders due to COVID-19 and electrolyte level abnormalities is one of them that affect the outcome of the patients.

Serum sodium levels over $145 \mathrm{mmol} / \mathrm{L}$ (hypernatremia) and below $135 \mathrm{mmol} / \mathrm{L}$ (hyponatremia) are independent risk factors for high mortality in hospitalized patients ${ }^{(6)}$. Some recent studies indicates that hypernatremia and hyponatremia is common in COVID-19 patients with a poor prognosis ${ }^{(7)}$. The cause of hypernatremia can be high sodium intake or loss of water ${ }^{(8)}$.

The aim of our study was to investigate the association of serum $\mathrm{Na}^{+}$levels with the clinical outcomes in hospitalized patients during their treatments. We investigated the mortality relationship, need for intubation and need for intensive care admission. We also analyzed the role of serum $\mathrm{Na}^{+}$as a predictive marker for COVID-19 immune response. For this purpose we used hs-CRP and serum Na correlations.

\section{MATERIAL and METHOD}

In this study we retrospectively investigated 1473 patients with the diagnosis of COVID-19 who attended to the emergency department of Bornova Turkan Ozilhan Hospital from the beginning of September 2020 to the end of December 2020. The Buca Seyfi Demirsoy hospital ethics board approved our study (2021/3-30). The COVID-19 diagnosis was confirmed with a positive real-time reverse transcriptasepolymerase chain reaction (RT-PCR) test on nasopharyngeal swab. The electronic medical record datas (laboratory files, treatment records and discharge summaries) of the hospital was used for our study. The demographic characteristics, all chronic diseases, detailed laboratory results and the clinical follow-up records were collected. All patients were treated according to the guidelines for the treatment of COVID-19 that were published by the Turkey Ministry of Health.

The sodium levels of all patients were recorded:

i) first blood sample in the admission to the emergency room,

ii) the blood sample on the second day

iii) the first blood sample in ICU stay (if ICU is needed)

iv) the last blood sample (before death or before the discharge from ICU).

v) the average of serum sodium level measurements calculated and called delta sodium.

If the patient was in a hyperglycemic state we used "Corrected $\mathrm{Na}^{+}=$serum $\mathrm{Na}$ level $+[1.6 \mathrm{meq} / \mathrm{L} \mathrm{x}$ (glucose-100)/100] ${ }^{(9)}$.

There were 223 patients with abnormal sodium results in one or more measurements during the treatment period. We excluded all of them from our study.

There were 939 normonatremic (serum $\mathrm{Na}^{+}=135$ $145 \mathrm{meq} / \mathrm{L}$ ) 231 hyponatremic (serum $\mathrm{Na}^{+}<135$ meq/L) and 80 hypernatremic patients (serum $\mathrm{Na}^{+}$ 
$>145 \mathrm{meq} / \mathrm{L}$ ) in their admission to the emergency room.

The plasma urea levels were used to make a differential diagnosis of hyponatremic states (euvolemic ve hypovolemic). A plasma urea $>5 \mathrm{mmol} / \mathrm{L}$ indicates hypovolemic hyponatremia and urea $<5 \mathrm{mmol} / \mathrm{L}$ specifies euvolemic hyponatremia with a predictive power of $80 \%$.

Among 80 hypernatremic patients 50 of them stayed hypernatremic despite all the treatments. Also among those 231 hyponatremic patients 110 stayed hyponatremic despite all treatments. Among those 939 normonatremic patients 418 stayed normonatremic in all their bood tests during their treatment. (Figure 1).

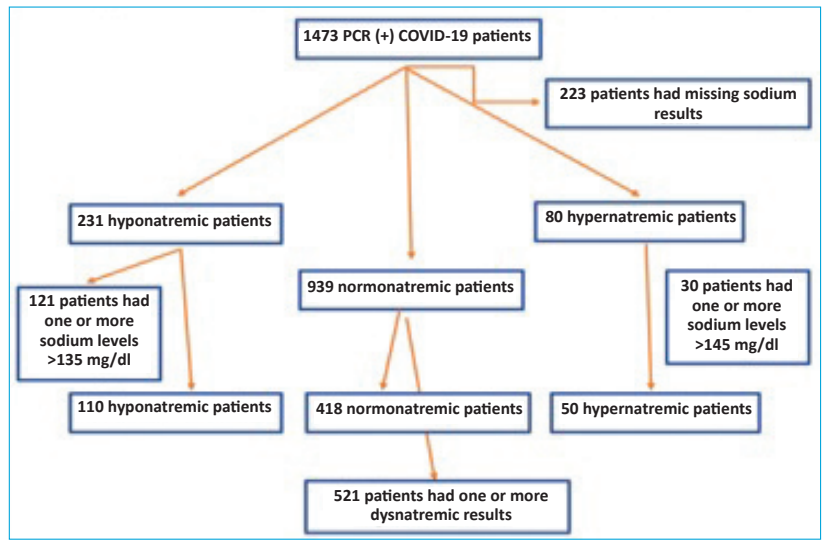

Figure 1.

\section{Variables:}

In this study the variables were analyzed at admission to the emergency unit and during the hospitalization. The admission variables that are continues datas were shown as median with interquartile range (IQR). The ones that are categorical variables were showed as number ( $\mathrm{n})$ with percentage (\%). The date that we collected during the admission files were date of admission, age, sex, medical history before this diagnosis, and all comorbidities [current or past] smoking, arterial hypertension, dyslipidemia, any cardio and cerebrovascular disease (CVD), obesity, diabetes mellitus (DM), advanced chronic kidney disease (CKD) defined as a creatinine clearan- ce $<30 \mathrm{~mL} / \mathrm{min}$, any chronic obstructive lung disease (COLD), any chronic liver disease, any cancer (past or current), medications (immunosuppressive drugs, corticosteroids, diuretics, angiotensin-2 receptor antagonists (ARB), angiotensin-converting enzyme inhibitors (ACEi)], as well as clinical manifestations [fever, shortness of breath, cough, tachycardia, tachypnea, anosmia, ageusia, nausea or vomiting, diarrhea, fatigue, headache, muscle pain]. We also recorded laboratory results like renal and kidney functions; the inflammation and coagulation markers (D-dimer, fibrinogen, hs-CRP and procalcitonin) were also recorded. We also recorded the cumulative water balance on the days of laboratory tests, the total water intake (oral and IV) and the urine volume for 24 hours. We used delta plasma sodium concentrations for investigating the correlations of biochemical markers and differences of negative outcomes among three groups.

We investigated mortality, need for intensive care unit, (ICU), need for advanced respiratory support, or intubation and invasive mechanical ventilation (IMV) as main outcomes.

\section{Statistical analysis}

We used SPSS 23.0 software for all statistical analyses. Continuous measurements with normal distribution were presented as mean and standard deviation (SD), while those that were not normally distributed were described in median (M) and interquartile range (IQR). Categorical variables, such as onsets of abnormal laboratory values, were described in counts of events and percentages. For continuous variables, single-factor analysis of variance (OneWay ANOVA) was used when normality (and homogeneity of variance) assumptions were satisfied, otherwise, the $\mathrm{K}$ Independent Sample Test of Nonparametric Test (Kruskal-Wallis Test) was used. Chi-square test and Fisher's exact test were used in the analysis of categorical variables. A Kaplan-Meier plot was used for survival data. Statistical significance was set at $p<0.05$. 


\section{RESULTS}

\section{The Characteristics of Patients:}

One thousand seventy tree patients with COVID-19 [53.9\% males (793 patients) and $46.1 \%$ females (680 patients)], were investigated for this study. Most of these patients (97\%) had either been exposed to a family member(s) who was infected $(66.3 \%)$ or a friend $(30.7 \%)$ only a few of them could not describe the source of infection (3\%). The admitted patients' clinical characteristics were fever (81.2\%), anosmia (73.5\%), ageusia (69.7\%), cough (70.9\%), fatigue (48.8\%), tachycardia (48.2\%), tachypnea (38.7\%), shortness of breath $(38,4 \%)$, nausea or vomiting (32.7\%), diarrhea (23.5\%), headache (41.3\%), muscle pain (39.7\%). When we checked the comorbidities hypertension (40.5\%) was the most common one followed by type 2 diabetes mellitus (35\%). The other comorbidities were hyperlipidemia (33.6\%), coronary heart disease (CHD) (23.9\%), chronic obstructive pulmonary disease (COPD) (3\%), cerebrovascular disease (CVD) (2.2\%), chronic kidney failure (CKD) (1.7\%), type 1 diabetes mellitus (1.6\%) and any kind of cancer (1.4\%).

\section{Comorbidities of patients:}

When we look at the characteristics of our groups in detail; the dysnatremic groups (Group-2 and Group-3) had more hypertensive patients than normonatremic group (Group-1) [167 patients vs 26 patients p $<0.01$ for Group 1 vs Group 2; 167 patients vs 51 patients $p<0.01$ for Group-1 vs Group-3; 26 patients vs 51 patients $p<0.05$ for Group- 2 vs Group-3]. The dysnatremic groups (Group-2 and Group-3) had more type 2 diabetic patients than normonatremic group (Group-1) [52 patients vs 30 patients $p<0.01$ for Group 1 vs Group 2; 52 patients vs 68 patients $\mathrm{p}<0.01$ for Group-1 vs Group-3; 30 patients vs 68 patients $p>0.05$ for Group-1 vs Group-2] When we look at the coronary heart disease (CHD) rates; the dysnatremic groups (Group-1 and Group-2) had also more CHD than normonatremic group (Group-3). [91 patients vs 42 patients $p<0.01$ for Group 1 vs Group 2; 91 patients vs 45 patients $p<0,01$ for Group-1 vs Group-3; 42 patients vs 45 patients $p<0.05$ for
Group-2 vs Group-3]. Detailed description of the characteristics of the total population and their subgroups according to the sodium levels are presented in Table 1.

\section{Biochemical Test Results:}

The results of the laboratory findings of our patients were summarized in Table 2 . The medians laboratory findings for hs-CRP, procalcitonin, fibrinogen, renal function tests, liver function tests and electrolyte levels were all within the normal ranges. Compared to Group-1 (normonatremic), patients in Group-3 (hyponatremic) had significantly higher hs-CRP, procalcitonin, fibrinogen, D-Dimer levels. The blood lipid were also elevated in Group-3 when we compare it with Group-1 results. The potassium levels were significantly higher and chlorine levels were significantly lower in Group-3 when we compare them to the results of Group-1. When we compare the results of hypernatremic patients (Group-2) with normonatremic ones (Group-1) the blood urea nitrogen (BUN), creatinine, total cholesterol and triglyceride levels were significantly higher. The serum potassium levels were lower but chloride levels were higher in Group-2 patients when we compare them with Group-1 patients. When we look at the results of fibrinogen, procalcitonin, hs-CRP and D-dimer Group-2 patients had significantly higher results than Group-2 patients. When we compare the dysnatremic groups Group-2 (hypernatremic) patients had higher BUN, total cholesterol and triglyceride levels than Group-3. The hypernatremic patients had significantly higher fibrinogen and D-Dimer levels when we compare them with hyponatremic ones. But procalcitonin and hs-CRP levels of Group-2 were significantly lower than Group-3.

\section{Treatment models and Complications of Patients:}

We used the treatment guidelines for COVID-19 of the Ministry of Health of Turkey for all of our patients. We analyzed the guideline and aim of enteral and parenteral administration of fluids, type and amount of medications, urine output, and fluid balance $(p>0.05)$. Perspiration was not considered in the fluid balance because assessment of amount and 
Table 1.

\begin{tabular}{|c|c|c|c|c|c|}
\hline & Total & Group-1 & Group-2 & Group-3 & P value \\
\hline & & Normonatremic & Hypernatremic & Hyponatremic & $P_{1}(1-2) P_{2}(1-3) P_{3}(2-3)$ \\
\hline Patients & 1473 & 418 & 50 & 110 & \\
\hline Age & $56(19-94)$ & $54(19-79)$ & $76,5(61-94)$ & $68(55-78)$ & $\mathrm{P}_{1}<0,05 ; \mathrm{P}_{2}<0,05 ; \mathrm{P}_{3}<0,01$ \\
\hline $\operatorname{Sex}(M / F)$ & $793 / 680$ & $212 / 206$ & $28 / 22$ & $62 / 48$ & \\
\hline \multicolumn{6}{|l|}{ Comorbities } \\
\hline Hypertension & $597(40,5 \%)$ & $167(40 \%)$ & $26(52 \%)$ & $51(46 \%)$ & $\mathrm{P}_{1}<0,01 ; \mathrm{P}_{2}<0,01 ; \mathrm{P}_{3}<0,05$ \\
\hline $\begin{array}{c}\text { Type } 2 \text { Diabetes } \\
\text { Mellitus }\end{array}$ & $515(35 \%)$ & $52(12,5 \%)$ & $30(60 \%)$ & $68(62 \%)$ & $\mathrm{P}_{1}<0,01 ; \mathrm{P}_{2}<0,01 ; \mathrm{P}_{3}>0,05$ \\
\hline Dyslipidemia & $495(33 \%)$ & $130(31 \%)$ & $30(60 \%)$ & $43(39 \%)$ & $\mathrm{P} 1<0,01 ; \mathrm{P}_{2}<0,05 ; \mathrm{P}_{3}<0,05$ \\
\hline Obesity & $499(33,8 \%)$ & $128(30 \%)$ & $26(52 \%)$ & $47(42,7 \%)$ & $\mathrm{P}_{1}<0,01 ; \mathrm{P}_{2}<0,01 ; \mathrm{P}_{3}<0,05$ \\
\hline Smoking & $383(25 \%)$ & $101(24,1 \%)$ & $21(42 \%)$ & $45(41 \%)$ & $\mathrm{P}_{1}<0,05 ; \mathrm{P}_{2}<0,05 ; \mathrm{P}_{3}>0,05$ \\
\hline $\begin{array}{c}\text { Cardiovascular } \\
\text { disease }\end{array}$ & $352(23,9 \%)$ & $91(21,7 \%)$ & $42(82 \%)$ & $45(40,9 \%)$ & $\mathrm{P}_{1}<0,01 ; \mathrm{P}_{2}<0,01 ; \mathrm{P}_{3}<0,01$ \\
\hline $\begin{array}{c}\text { Cerebrovascular } \\
\text { disease }\end{array}$ & $33(2,2 \%)$ & $0(0 \%)$ & $12(24 \%)$ & $10(9,1 \%)$ & $\mathrm{P}_{1}<0,01 ; \mathrm{P}_{2}<0,01 ; \mathrm{P}_{3}<0,01$ \\
\hline $\begin{array}{c}\text { Chronic kidney } \\
\text { disease }\end{array}$ & $25(1,7 \%)$ & $1(0,1 \%)$ & $9(18 \%)$ & $8(7,2 \%)$ & $\mathrm{P}_{1}<0,01 ; \mathrm{P}_{2}<0,01 ; \mathrm{P}_{3}<0,01$ \\
\hline $\begin{array}{c}\text { Type } 1 \text { Diabetes } \\
\text { Mellitus }\end{array}$ & $24(1,6 \%)$ & $3(0,7 \%)$ & $2(4 \%)$ & $2(1,8 \%)$ & $\mathrm{P}_{1}<0,01 ; \mathrm{P}_{2}<0,05 ; \mathrm{P}_{3}<0,05$ \\
\hline Chronic liver disease & $21(1,4 \%)$ & $4(0,9 \%)$ & $2(4 \%)$ & $3(2,7 \%)$ & $\mathrm{P}_{1}<0,01 ; \mathrm{P}_{2}<0,01 ; \mathrm{P}_{3}<0,05$ \\
\hline Cancer & $22(1,4 \%)$ & $2(0,5 \%)$ & $0(0 \%)$ & $0(0 \%)$ & $\mathrm{P}_{1}<0,01 ; \mathrm{P}_{2}<0,01 ; \mathrm{P}_{3}>0,05$ \\
\hline Immunosuppression & $16(1 \%)$ & $3(0,7 \%)$ & $0(0 \%)$ & $0(0 \%)$ & $\mathrm{P}_{1}<0,01 ; \mathrm{P}_{2}<0,01 ; \mathrm{P}_{3}>0,05$ \\
\hline ACEi/ARB & $541(36,7 \%)$ & $118(28 \%)$ & $34(68 \%)$ & $37(33 \%)$ & $\mathrm{P}_{1}<0,05 ; \mathrm{P}_{2}<0,05 ; \mathrm{P}_{3}<0,05$ \\
\hline \multicolumn{6}{|l|}{ Clinical Presentation } \\
\hline fever & $1196(81,2 \%)$ & $335(80 \%)$ & $41(82 \%)$ & $86(78 \%)$ & $\mathrm{P}_{1}>0,05 ; \mathrm{P}_{2}>0,05 ; \mathrm{P}_{3}>0,05$ \\
\hline anosmia & $301(20,5 \%)$ & $79(19 \%)$ & $9(18 \%)$ & $22(20 \%)$ & $\mathrm{P}_{1}>0,05 ; \mathrm{P}_{2}><0,05 ; \mathrm{P}_{3}>0,05$ \\
\hline ageusia & $295(20 \%)$ & $71(17,2 \%)$ & $9(18 \%)$ & $22(20 \%)$ & $\mathrm{P}_{1}>0,05 ; \mathrm{P}_{2}<0,05 ; \mathrm{P}_{3}<0,05$ \\
\hline cough & $1044(70,9 \%)$ & $296(70,8 \%)$ & $36(72 \%)$ & $81(73,5 \%)$ & $\mathrm{P}_{1}>0,05 ; \mathrm{P}_{2}>0,05 ; \mathrm{P}_{3}>0,05$ \\
\hline fatigue & $719(48,8 \%)$ & $214(51 \%)$ & $26(52 \%)$ & $55(50 \%)$ & $\mathrm{P}_{1}>0,05 ; \mathrm{P}_{2}>0,05 ; \mathrm{P}_{3}>0,05$ \\
\hline tachycardia & $710(48,2 \%)$ & $221(52,8 \%)$ & $39(78 \%)$ & $70(63,6 \%)$ & $\mathrm{P}_{1}<0,01 ; \mathrm{P}_{2}<0,05 ; \mathrm{P}_{3}<0,05$ \\
\hline headache & $608(41,3 \%)$ & $165(39,1 \%)$ & $24(48 \%)$ & $52(47,2 \%)$ & $\mathrm{P}_{1}<0,01 ; \mathrm{P}_{2}<0,01 ; \mathrm{P}_{3}>0,05$ \\
\hline muscle pain & $585(39,7 \%)$ & $158(37,7 \%)$ & $20(40 \%)$ & $43(39 \%)$ & $\mathrm{P}_{1}>0,05 ; \mathrm{P}_{2}>0,05 ; \mathrm{P}_{3}>0,05$ \\
\hline tachypnea & $570(38,7 \%)$ & $162(38,7 \%)$ & $22(4 \%)$ & $54(49 \%)$ & $\mathrm{P}_{1}<0,01 ; \mathrm{P}_{2}<0,01 ; \mathrm{P}_{3}<0,05$ \\
\hline shortness of breath & $565(38,4 \%)$ & $163(39 \%)$ & $30(60 \%)$ & $47(42,8 \%)$ & $\mathrm{P}_{1}<0,01 ; \mathrm{P}_{2}<0,01 ; \mathrm{P}_{3}<0,01$ \\
\hline nausea or vomiting & $482(32,7 \%)$ & $29(30 \%)$ & $16(32 \%)$ & $36(32,7 \%)$ & $\mathrm{P}_{1}>0,05 ; \mathrm{P}_{2}>0,05 ; \mathrm{P}_{3}>0,05$ \\
\hline diarrhea & $346(23,5 \%)$ & $101(24,1 \%)$ & $15(30 \%)$ & $30(27 \%)$ & $\mathrm{P}_{1}>0,05 ; \mathrm{P}_{2}<0,05 ; \mathrm{P}_{3}<0,05$ \\
\hline
\end{tabular}

composition is unreliable. All patients were euvolemic.

The need for length of hospitalization was significantly higher in dysnatremic groups than normonatremic group [ $13 \pm 1.7$ days vs $26 \pm 4.5$ days for Group -1 and Group-2 respectively $\mathrm{p} 1<0.01 ; 13 \pm 1.7$ days vs $19 \pm 3,1$ days for Group -1 and Group-3 respectively p2<0.01]. Hypernatremic patients needed longer hospital treatments than hyponatremic patient group [ $26 \pm 4.5$ days vs $19 \pm 3.1$ days for Group-2 and Group-3 respectively $\mathrm{p} 3<0.05]$. The need for intensive care unit treatment in Group-2 (hypernatremic patients) were significantly higher than the other two groups. [89 (21\%) patients vs $38(76 \%)$ patients for Group-1 and Group-2 respectively p1<0.01; 89 
Table 2.

\begin{tabular}{|c|c|c|c|c|c|}
\hline & Total & Group-1 & Group-2 & Group-3 & $P$ value \\
\hline & & Normonatremic & Hypernatremic & Hyponatremic & $P_{1}(1-2) P_{2}(1-3) P_{3}(2-3)$ \\
\hline Leuk. count $\times 106 / \mathrm{L}$ & $5392 \pm 1870$ & $5352 \pm 1798$ & $5419 \pm 1389$ & $5315 \pm 1980$ & $\mathrm{P}_{1}<0,01 ; \mathrm{P}_{2}<0,05 ; \mathrm{P}_{3}<0,01$ \\
\hline Neut. count $\times 106 / \mathrm{L}$ & $3900 \pm 892$ & $3921 \pm 876$ & $4101 \pm 865$ & $4894 \pm 912$ & $\mathrm{P}_{1}>0,05 ; \mathrm{P}_{2}<0,01 ; \mathrm{P}_{3}<0,05$ \\
\hline Lymph. count $\times 106 / L$ & $1097 \pm 901$ & $1099 \pm 872$ & $907 \pm 798$ & $766 \pm 888$ & $\mathrm{P}_{1}<0,05 ; \mathrm{P}_{2}<0,01 ; \mathrm{P}_{3}<0,05$ \\
\hline Platelet $\times 109 / \mathrm{L}$ & $199 \pm 102$ & $189 \pm 142$ & $202 \pm 139$ & $201 \pm 119$ & $\mathrm{P}_{1}>0,05 ; \mathrm{P}_{2}>0,05 ; \mathrm{P}_{3}>0,05$ \\
\hline Glucose & $121 \pm 19$ & $103 \pm 16$ & $145 \pm 13$ & $148 \pm 17$ & $\mathrm{P}_{1}<0,05 ; \mathrm{P}_{2}<0,05 ; \mathrm{P}_{3}>0,05$ \\
\hline BUN & $16 \pm 3,4$ & $15 \pm 3,3$ & $27 \pm 2,2$ & $21 \pm 4,1$ & $\mathrm{P}_{1}<0,01 ; \mathrm{P}_{2}<0,01 ; \mathrm{P}_{3}<0,01$ \\
\hline Creatinine & $0,9 \pm 0,1$ & $0,7 \pm 0,3$ & $1,1 \pm 0,4$ & $1,1 \pm 0,2$ & $\mathrm{P}_{1}<0,01 ; \mathrm{P}_{2}<0,01 ; \mathrm{P}_{3}>0,05$ \\
\hline SGOT & $41,2 \pm 2,2$ & $41,1 \pm 2,3$ & $40,8 \pm 2,1$ & $40,9 \pm 3,1$ & $\mathrm{P}_{1}>0,05 ; \mathrm{P}_{2}>0,05 ; \mathrm{P}_{3}>0,05$ \\
\hline SGPT & $38,1 \pm 1,8$ & $38,0 \pm 1,3$ & $42,2 \pm 1,4$ & $45,3 \pm 1,9$ & $\mathrm{P}_{1}>0,05 ; \mathrm{P}_{2}>0,05 ; \mathrm{P}_{3}>0,05$ \\
\hline ALP & $74,2 \pm 2.3$ & $73,1 \pm 2,9$ & $53,7 \pm 2,1$ & $72,9 \pm 3,1$ & $\mathrm{P}_{1}<0,01 ; \mathrm{P}_{2}>0,05 ; \mathrm{P}_{3}<0,01$ \\
\hline GGT & $143,3 \pm 8,9$ & $129,2 \pm 6,9$ & $131,7 \pm 7,3$ & $165,1 \pm 7,9$ & $\mathrm{P}_{1}>0,05 ; \mathrm{P}_{2}<0,01 ; \mathrm{P}_{3}<0,01$ \\
\hline URIC ACID & $5,9 \pm 1,6$ & $6,0 \pm 1,3$ & $5,9 \pm 1,4$ & $5,8 \pm 1,1$ & $\mathrm{P}_{1}>0,05 ; \mathrm{P}_{2}>0,05 ; \mathrm{P}_{3}>0,05$ \\
\hline T Chol. mg/dL & $231 \pm 14,1$ & $221 \pm 12,7$ & $262 \pm 13,6$ & $249,5 \pm 9,3$ & $\mathrm{P}_{1}<0,01 ; \mathrm{P}_{2}<0,01 ; \mathrm{P}_{3}<0,01$ \\
\hline TG mg/dL & $140,2 \pm 8,8$ & $139 \pm 4,1$ & $188 \pm 5,3$ & $169,3 \pm 6,3$ & $\mathrm{P}_{1}<0,01 ; \mathrm{P}_{2}<0,01 ; \mathrm{P}_{3}<0,05$ \\
\hline K & $3,4 \pm 0,5$ & $3,5 \pm 0,4$ & $3,3 \pm 0,5$ & $3,7 \pm 0,9$ & $\mathrm{P}_{1}<0,05 ; \mathrm{P}_{2}<0,05 ; \mathrm{P}_{3}<0,05$ \\
\hline $\mathrm{Cl} \mathrm{mmol/L}$ & $103,4 \pm 4,7$ & $104,2 \pm 3,9$ & $109,2 \pm 2,1$ & $99,2 \pm 3,3$ & $\mathrm{P}_{1}<0,01 ; \mathrm{P}_{2}<0,01 ; \mathrm{P}_{3}<0,01$ \\
\hline Fibrinogen, mg/dL & $368 \pm 2.0$ & $347 \pm 8,2$ & $398 \pm 7,6$ & $362 \pm 129$ & $\mathrm{P}_{1}<0,01 ; \mathrm{P}_{2}<0,05 ; \mathrm{P}_{3}<0,01$ \\
\hline Procalcitonin, ng/ml & $0,03 \pm 0,1$ & $0,03 \pm 0,05$ & $0,08 \pm 0,09$ & $0,10 \pm 0,09$ & $\mathrm{P}_{1}<0,05 ; \mathrm{P}_{2}<0,01 ; \mathrm{P}_{3}<0,05$ \\
\hline HS-CRP, mg/L, & $24 \pm 27,3$ & $19 \pm 11,2$ & $31,3 \pm 19,1$ & $38,7 \pm 21,3$ & $\mathrm{P}_{1}<0,01 ; \mathrm{P}_{2}<0,01 ; \mathrm{P}_{3}<0,05$ \\
\hline D-Dimer, ug/ml & $1,1 \pm 0,9$ & $1,0 \pm 0,8$ & $5,3 \pm 1,2$ & $3,9 \pm 1,3$ & $\mathrm{P}_{1}<0,01 ; \mathrm{P}_{2}<0,01 ; \mathrm{P}_{3}<0,05$ \\
\hline
\end{tabular}

(21\%) patients vs 42 (38\%) patients for Group-1 and Group-3 respectively $\mathrm{p} 2<0.05 ; 38(76 \%)$ patients vs 42 (38\%) patients for Group-2 and Group-3 p3<0.05]. The mortality rate was also significantly higher in hypernatremic group patients (Group-2) than the rest of the patient groups. [21 (5\%) patients vs 25 (50\%) patients for Group-1 and Group-2 respectively p1<0.01; 21 (5\%) patients vs 31 (28\%) patients for Group-1 and Group-3 respectively p2<0.05; 25 (50\%) patients vs (38\%) patients for Group-2 and Group-3 p3<0.05]. All. Treatment and outcome data were summarized in Table 3.

In fact, the increase in the risk of death was directly associated with serum sodium ( $\mathrm{SNa}$ ) levels. Univariable Cox regression analysis showed a higher hazard ratio (HR) for mortality for SNa levels $<135 \mathrm{mmol} / \mathrm{L}$ as well as $>145 \mathrm{mmol} / \mathrm{L}$ than those between 135 and 145 $\mathrm{mmol} / \mathrm{L}$. The Kaplan-Meier Survival curve according to sodium levels is shown in (Figure 2). 
Table 3.

\begin{tabular}{|c|c|c|c|c|c|}
\hline & Total & Group-1 & Group-2 & Group-3 & $P$ value \\
\hline & & Normonatremic & Hypernatremic & Hyponatremic & $P_{1}(1-2) P_{2}(1-3) P_{3}(2-3)$ \\
\hline Hospitalization (days) & $21 \pm 12,2$ & $13 \pm 1,7$ & $26 \pm 4,5$ & $19 \pm 3,1$ & $\mathrm{P}_{1}<0,01 ; \mathrm{P}_{2}<0,01 ; \mathrm{P}_{3}<0,05$ \\
\hline $\begin{array}{c}\text { Intensive Care Unit } \\
\text { (patients) }\end{array}$ & 310 & $89(21,5 \%)$ & $38(76 \%)$ & $71(64 \%)$ & $\mathrm{P}_{1}<0,01 ; \mathrm{P}_{2}<0,01 ; \mathrm{P}_{3}<0,05$ \\
\hline Intensive Care Unit (days) & $16 \pm 6,4$ & $10 \pm 3,1$ & $21 \pm 2,1$ & $17 \pm 2,2$ & $\mathrm{P}_{1}<0,01 ; \mathrm{P}_{2}<0,01 ; \mathrm{P}_{3}<0,01$ \\
\hline Intubation (patients) & 249 & $70(16 \%)$ & $29(58 \%)$ & $42(38 \%)$ & $\mathrm{P}_{1}<0,05 ; \mathrm{P}_{2}<0,05 ; \mathrm{P}_{3}>0,05$ \\
\hline Intubation (days) & $11 \pm 3,2$ & $10 \pm 1,9$ & $17 \pm 2,2$ & $14 \pm 2,3$ & $\mathrm{P}_{1}<0,01 ; \mathrm{P}_{2}<0,05 ; \mathrm{P}_{3}<0,05$ \\
\hline Death (patients) & 89 & $21(5 \%)$ & $25(50 \%)$ & $31(28 \%)$ & $\mathrm{P}_{1}<0,01 ; \mathrm{P}_{2}<0,01 ; \mathrm{P}_{3}<0,05$ \\
\hline
\end{tabular}

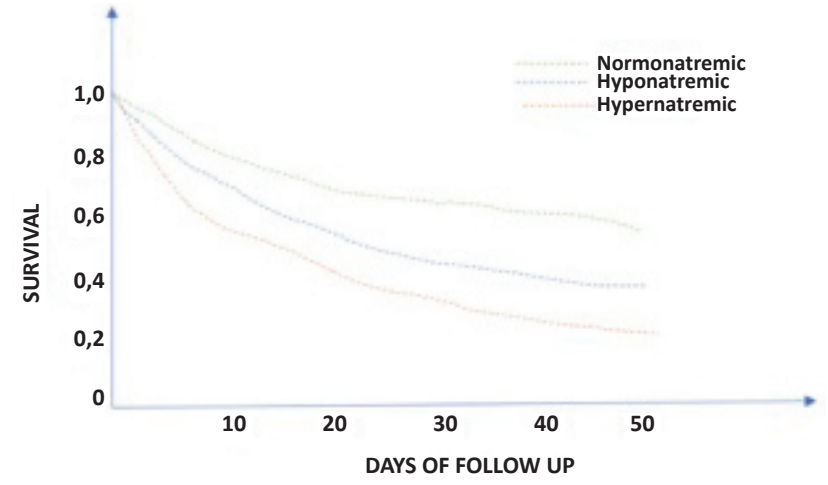

Figure 2.

\section{DISCUSSION}

Our study demonstrated that dysnatremia in COVID19 patients is independently associated with high ICU admission, high intubation need and high mortality. Hypernatremia is associated with worse outcomes than hyponatremia. In this study we retrospectively investigated 1473 COVID-19 (+) patients. Our study showed that -according to the first blood test results- hyponatremia affected more than $15 \%$ of the patients (231 patients). Conversely, hypernatremia affected only $5.4 \%$ of the patients ( 80 patients). These findings verified the prior study reports about COVID and dysnatremia ${ }^{(9-11)}$.

Different mechanisms may cause the increased prevalence of sodium abnormilities in COVID-19 pneu- monia. The inappropriate antidiuresis syndrome (SIAD), hyponatremia which is induced by drugs (mainly diuretics or psychotropics) could be the reason for hyponatremia. There is an important hypothesis that suggests the hyponatremia developments is due to immune system deficiencies in patients with COVID-19 pneumonia. In a meta-analysis of COVID-19 patients, Henry et. al. ${ }^{(12)}$ demonstrated higher prevalence of elevated IL-1 and IL- 6 levels. IL- 6 causes a non-osmotically release of arginine vasopressin (AVP) and this plays a significant role in sodium homeostasis. Berni et al. ${ }^{(13)}$ showed an improvement of hyponatremia after anti-IL- 6 therapy, this is an important finding that supports this theory. In our study we demonstrated significantly an elevated neutrophil counts and hs-CRP levels in hyponatremic patients. This finding can also be a support to this theory.

Post et al. ${ }^{(14)}$ indicates that dysnatremia may have a possible role in the regulation of ACE2. They suggest an upregulation of ACE2 resulting from low sodium levels. This upregulation on epithelial cells aggravates intracellular virus transport rate. This higher virus load can be the reason for negative outcomes related to hyponatremia.

In our study we demonstrated a higher mortality rate associated with hypernatremia. Water loss can 
be the main reason for hypernatremia and can be the result of increased body temperature ${ }^{(15)}$. Fever was one of the most common symptoms in our analysis and could therefore partly explain the high rate of hypernatremia. We also demonstrated higher rates of vomiting and diarrhea in our hypernatremic patients. In the study from Ruiz-Sanchez et al. (7) demonstrated higher rates of nausea and vomiting in hypernatremic patients similar to our study and fewer rates of diarrhea which is opposite in our study. These symptoms may cause water loss and can be the reason for the hypernatremia at the attendance to the hospital. But our patients had proper IV serum and electrolyte supplementation which exclude the reason for persistent hypernatremia. We demonstrated significantly higher rates of tachypnea in our hypernatremic group. This findings are similar to some previous studies ${ }^{(7-9)}$.

The high rates of tachypnea in both hypernatremic and hyponatremic patients is similar to the HOPE COVID-19 study (7). Tachypnea causes insensible water loss which may explain the higher incidence in hyponatremic patients. Unfortunetely we could'nt calculate this part of water loss when we plan our treatment. The high incidence of tachypnea in hypernatremic patients may be another reason for the cause of dysnatremia ${ }^{(16)}$. More studies are needed to explain this mechanism and findings.

The main limitation of our study is that there were no available records of oral fluid and food intakes and this causes some doubts in the treatment of sodium balance. It causes difficulties for explanation the etiology of dysnatremia. But whatever the etiology of dysnatremia is, dysnatremia is associated with higher rates of longer hospitalization, need for intensive care unit and higher mortality.

In the past year we realized some biochemical markers that predicts negative outcomes. Also we realized some risk factors that give raise to a higher mortality rate ${ }^{(2)}$. Sodium is a parameter that is widely studied and has a low cost. This can make it a useful marker for prognosis of Covid-19 patients in the primary care system and in small town hospitals.

Ethics Committee Approval: Buca Seyfi Demirsoy Training and Research Hospital Non-Interventional Research Ethics Committee approval was obtained (31.03.2021/3-30).

\section{Conflict of Interest: None.}

Funding: None.

Informed Consent: Receipt.

\section{REFERENCES}

1. Ozma MA, Maroufi P, Khodadadi E, Köse Ş, Esposito I, Ganbarov K, et al. Clinical manifestation, diagnosis, prevention and control of SARS-CoV-2 (COVID-19) during the outbreak period. Infez Med. 2020 Ahead of print Jun 1;28(2):15365. PMID: 32275257.

2. Li H, Burm SW, Hong SH, Ghayda RA, Kronbichler A, Smith L, et al. A Comprehensive Review of Coronavirus Disease 2019: Epidemiology, Transmission, Risk Factors, and International Responses. Yonsei Med J. 2021;62(1):1-11. [CrossRef]

3. Yüce $M$, Filiztekin $E$, Özkaya KG. COVID-19 diagnosis -A review of currentmethods. Biosens Bioelectron. 2021;172:112752. [CrossRef]

4. Wool GD, Miller JL. The Impact of COVID-19 Disease on Platelets and Coagulation. Pathobiology. 2021;88(1):15-27. [CrossRef]

5. Gustine JN, Jones D. Immunopathology of Hyperinflammation in COVID-19. Am J Pathol. 2021;191(1):4-17. [CrossRef]

6. Atila C, Sailer CO, Bassetti S, Tschudin-Sutter S, Bingisser R, Siegemund $M$, et al. Prevalence and outcome of dysnatremia in patients with COVID-19 compared to controls. Eur J Endocrinol. 2021;184(3):409-18. [CrossRef]

7. Ruiz-Sánchez JG, Núñez-Gil IJ, Cuesta M, Rubio MA, MarounEid C, Arroyo-Espliguero R, et al. HOPE COVID-19 investigators. Prognostic Impact of Hyponatremia and Hypernatremia in COVID-19 Pneumonia. A HOPE-COVID-19 (Health Outcome Predictive Evaluation for COVID-19) Registry Analysis. Front Endocrinol (Lausanne). 2020;11:599255. [CrossRef]

8. Voets PJ, Frölke SC, Vogtländer NP, Kaasjager KA. COVID-19 and dysnatremia: A comparison between COVID-19 and non-COVID-19 respiratory illness. SAGE Open Med. 2021;9:20503121211027778. [CrossRef]

9. Barski L, Eshkoli T, Brandstaetter E, Jotkowitz A. Euglycemic diabetic ketoacidosis. Eur J Intern Med. 2019;63:9-14. [CrossRef]

10. Tzoulis P, Waung JA, Bagkeris E, Hussein Z, Biddanda A, Cousins J, et al. Dysnatremia is a Predictor for Morbidity and Mortality in Hospitalized Patients with COVID-19. J Clin Endocrinol Metab. 2021;106(6):1637-48. [CrossRef]

11. Fernandez Martinez A, Barajas Galindo D, Ruiz Sanchez J. Management of hyponatraemia and hypernatraemia during the Covid-19 pandemic: a consensus statement of the Spanish Society for Endocrinology (Acqua Neuroendocrinology Group). Rev Endocr PMID: 33547563; PMCID: PMC7864617.

12. Henry BM, de Oliveira MHS, Benoit S, Plebani M, Lippi G. Hematologic, biochemical and immune biomarker abnorma- 
lities associated with severe illness and mortality in coronavirus disease 2019 (COVID-19): a meta-analysis. Clin Chem Lab Med. 2020;58(7):1021-8. [CrossRef]

13. Berni A, Malandrino D, Parenti G, Maggi M, Poggesi L, Peri A. Hyponatremia, IL-6, and SARS-CoV-2 (COVID-19) infection: may all fit together? J Endocrinol Invest. 2020;43(8):1137-9. [CrossRef]

14. Post A, Dullaart RPF, Bakker SJL. Sodium status and kidney involvement during COVID-19 infection. Virus Res.
2020;286:198034. [CrossRef]

15. Zimmer MA, Zink AK, Weißer CW, Vogt $U$, Michelsen A, Priebe $\mathrm{HJ}$, et al. Hypernatremia-A Manifestation of COVID19: A Case Series. A A Pract. 2020;14(9):e01295. [CrossRef]

16. Lim JH, Jung HY, Choi JY, Park SH, Kim CD, Kim YL, et al. Hypertension and Electrolyte Disorders in Patients with COVID-19. Electrolyte Blood Press. 2020;18(2):23-30. [CrossRef] 